\title{
PERBANDINGAN LOGISTIC PERFORMANCE INDEX (LPI) DAN PURCHASING MANAGER'S INDEX (M-PMI) DALAM MENGEVALUASI KINERJA LOGISTIK INDONESIA
}

\author{
SUBEKTI ${ }^{1}$ DEVI JAYAWATI ${ }^{2}$ \\ Program Studi Manajemen Logistik Politeknik APP Jakarta \\ E-mail: bekti.rambar@gmail.com ${ }^{1}$
}

DOI Number : $\underline{10.30988 / \text { imil.v1i1.9 }}$

\begin{abstract}
The effectiveness of Logistics system is the main pillar for national industry and trade development and also for foreign investment attractiveness. Logistics performance at the macro or national level is evaluated using LPI (Logistics Performance Index) that issued by the World Bank. Beside that, the other one of economic indicators is M-PMI (Manufacturing Purchasing Managers Index) that evaluates the economic development of a country whether there is an increasing of the level of production, delivery of goods by the supplier, and inventory levels in the processing industry. This study fills a gap in assessing the relationship between LPI dan M-PMI. This study discusses the three things, firstly the condition of LPI Indonesia and the potential for improvement, secondly conditions M-PMI Indonesia 2013 - 2015, and thirdly, the relationship between M-PMI and LPI which analyze the impact of the changes of LPI values to the value of M-PMI. We use comparative analysis qualitatively. From the data analysis of LPI value in 2014 it shows that compared to the other ASEAN countries, Indonesia still needs a lot of improvement in customs clearance and delivery components. From the M-PMI curve it shows that when Indonesia's LPI is 2,94 in 2012 the value of Indonesia's M-PMI fluctuate with variation of 2.29. Meanwhile, when Indonesia's LPI is 3.08 in 2014, the value of the Indonesia's MPMI more stable with a variation of 1, 69. We can conclude that the condition M-PMI will be more stable when the LPI is higher, but the movement of M-PMI was not significantly affected by LPI itself but rather on economic conditions, especially the interest rate, purchasing power, and the productivity of the manufacturing industry.
\end{abstract}

Keywords: LPI, M-PMI, Logistics

\begin{abstract}
Abstrak
Sistem logistik yang efektif dan efisien tidak hanya menjadi ujung tombak pembangunan industri dan perdagangan nasional namun juga sebagai daya tarik investasi asing. Kinerja logistik pada tingkat makro atau nasional dievaluasi menggunakan LPI (Logistics Performance Index) yang dikeluarkan oleh Bank Dunia. Disisi lain ada indikator perekonomian yang berupa M-PMI (Manufacturing Purchasing Manager Index) yang mengevaluasi perkembangan ekonomi suatu negara dengan menilai ada tidaknya peningkatan dari tingkat produksi, pengiriman barang oleh pemasok, dan tingkat persediaan dalam industri pengolahan. Penelitian ini mengisi celah dalam mengkaji hubungan mPMI dengan LPI. Penelitian ini membahas tiga hal, pertama kondisi LPI Indonesia dan potensi perbaikannya, kedua kondisi M-PMI Indonesia tahun 2013 - 2015, dan ketiga, hubungan mPMI dengan LPI yaitu membahas kondisi perubahan mPMI Indonesia untuk capaian nilai LPI yang berbeda-beda. Metode yang digunakan adalah metode komparatif secara kualitatif. Dari analisa data didapatkan bahwa untuk LPI Indonesia dibandingkan Negara ASEAN lainnya adalah Indonesia masih memerlukan banyak perbaikan
\end{abstract}


pada komponen kepabeanan dan pengiriman. Adapun untuk kurva M-PMI, untuk LPI = 2,94 pada tahun 2012 M-PMI Indonesia mengalami variasi yang cukup lebar yaitu 2,29 sedangkan pada nilai LPI 3,08 pada tahun 2014 nilai M-PMI Indonesia lebih stabil dengan variasi sebesar 1,69. Kesimpulan yang didapatkan dari penelitan ini adalah walaupun kondisi M-PMI lebih stabil pada saat LPI lebih tinggi, namun pergerakan M-PMI tidak secara signifikan dipengaruhi oleh LPI itu sendiri namun lebih pada kondisi ekonomi terutama tingkat suku bunga, daya beli masyarakat, dan produktivitas industri manufaktur.

Kata kunci: Logistics Performance Index, Manufacturing PMI, Logistik

\section{PENDAHULUAN}

Logistik merupakan salah satu kunci keberhasilan sektor industri dan perdagangan. Kemampuan suatu negara dalam mengelola logistiknya secara efektif dan efisien dapat meningkatkan daya saing negara tersebut. Saat ini kemampuan industri Indonesia dalam menghasilkan produk barang dan jasa dengan biaya yang lebih rendah dibanding pesaing masih sulit dilakukan. Hal ini dikarenakan kinerja logistik indonesia yang masih jauh dari memuaskan. Dapat dilihat dari nilai Logistics Performance Index (LPI) yang dirilis oleh Bank Dunia, dimana data terakhir menyebutkan bahwa Indonesia berada pada peringkat ke-53 dari 160 negara. LPI adalah indeks yang menggambarkan kinerja logistik suatu negara dilihat dari beberapa indikator yang diperoleh dari hasil survei terhadap. LPI merupakan salah satu indeks yang dijadikan pertimbangan oleh para investor dalam melakukan investasi industri di suatu negara.

Beberapa penelitian tentang LPI telah dilakukan antara lain Ojala dan Celebi (2015) yang menganalisis kinerja logistik negara dalam kaitannya dengan komponen kebijakan yang mempengaruhi peraturan, prosedur, dan operasi logistik dan perdagangan dengan studi kasus negara Turki. Pada tahun 2014 Bizoi and Sipos meneliti tentang performansi logistik dan pengembangan ekonomi melalui studi komparasi terhadap negara-negara yang tergabung dalam Uni Eropa melalui dua indikator yaitu LPI dan Gross Domestic Product (GDP).

Selain itu, terdapat pula indikator yang digunakan praktisi pasar modal untuk investasi industri yakni PMI (Purchasing Manager's Index). Penelitian dengan menggunakan PMI masih terbilang belum banyak dilakukan. Kang dan Yang (2013: 6174-6177) menganalisis korelasi antara FDI inflows dengan m-PMI untuk mengukur pembangunan nasional sektor industri di Cina. Hasilnya mereka menemukan FDI memiliki pengaruh positif terhadap m-PMI, namun tidak berlaku sebaliknya. Khundrakpam dan George (2012) melakukan analisa empiris tentang hubungan antara WPI dengan M-PMI di India. Dari penelitian ini ditemukan bahwa M-PMI dapat dijadikan sebagai indikator yang bagus dalam memprediksi perubahan pada WPI. Sementara itu Aprigliano (2011) menganalisis kaitan antara PMI dengan Industrial Production Index (IPI) dengan mempertimbangkan pengaruh krisis ekonomi yang baru terjadi.

Terdapat empat point rumusan masalah yang ingin dibahas dalam penelitian ini. Pertama, bagaimana kinerja logistik Indonesia dilihat dari LPI dan M-PMI. Kedua, bagaimana posisi kinerja logistik Indonesia dibandingkan dengan negara ASEAN lainnya. Ketiga, apa saja upaya-upaya yang dapat dilakukan untuk perbaikan kinerja logistik Indonesia. Yang terakhir, apakah ada keterkaitan antara LPI dan M-PMI. Adapun tujuan dari penelitian ini sebagai berikut: (i) mengetahui bagaimana kinerja logistik Indonesia dilihat dari LPI dan M-PMI, (ii) mengetahui bagaimana posisi kinerja logistik Indonesia dibandingkan dengan negara ASEAN lainnya, (iii) menetapkan upaya-upaya yang dapat dilakukan untuk perbaikan kinerja logistik Indonesia, dan (iv) mengetahui apakah ada keterkaitan antara LPI dan M-PMI.

Penelitian ini mencoba mengevaluasi kinerja logistik Indonesia melalui indikator indeks LPI. Selain itu juga akan dianalisa bagaimana kaitan antara LPI dengan indikator industri yakni MPMI. Studi komparatif juga dilakukan dengan membandingkan LPI dan M-PMI Indonesia dibandingkan dengan negara ASEAN lainnya. Sistematika penulisan pada penelitian ini terdiri dari lima bagian, yaitu: (i) Pendahuluan, (ii) landasan teori, (iii) metode penelitian, (iv) hasil dan pembahasan, serta (v) kesimpulan dan saran. 


\section{LANDASAN TEORI}

Bab ini akan membahas studi literatur penelitian ini ke dalam 4 (empat) bagian, yaitu studi literatur tentang Industri Manufaktur, LPI, PMI, serta penelitian terdahulu yang mendasari penelitian ini.

\section{Logistik}

Pengertian logistik menurut Council of Logsitics Management adalah sebuah proses perencanaan, penerapan dan pengawasan secara efisien, efektif, aliran dan penyimpanan barang, jasa dan informasi terkait dari titik asal ke titik konsumsi yang bertujuan untuk memenuhi kesesuaian kebutuhan konsumen. Tujuan utama dari logistik adalah memenuhi kebutuhan barang yang tepat, pada waktu yang tepat, dengan jumlah yang tepat, kondisi yang tepat, dengan biaya yang terjangkau, dengan tetap memberikan kontribusi profit bagi penyedia jasa logistik. Untuk memenuhi hal ini maka diperlukan sistem logistik yang baik yakni yang dapat menjamin kelancaran arus barang secara efektif dan efisien yang tercermin dari 2 hal yaitu biaya logistik yang rendah serta pelayanan yang responsif dan memuaskan.

\subsection{Logistic Performance Index (LPI)}

LPI merupakan salah satu indikator yang menilai kinerja sektor logistik suatu negara. Indikator ini dikeluarkan oleh World Bank (Bank Dunia) berdasarkan dari data yang survey yang dilakukan terhadap profesional logistik di negara-negara di dunia mengenai persepsi mereka terhadap efisiensi logistik yang dipengaruhi oleh beberapa komponen antara lain customs (kepabeanan), infrastruktur transportasi dan perdagangan, shipments, layanan logistik, merchandise tracebility, serta on time delivery. The World Bank menghitung nilai LPI berdasarkan dari data yang survey yang dilakukan terhadap pelaku transportasi.

Terdapat 6 komponen pengukuran yang digunakan untuk menghitung LPI, yaitu kepabeanan, kualitasinfrastruktur transportasi dan perdagangan, shipment (terkait kemudahan mengatur pengapalan internasional yang berpengaruh kepada harga pengapalan yang kompetitif), kompetensi dan kualitas layanan logistik, kemampuan untuk pelacakan dan penelusuran pengiriman, serta on time delivery (terkait dengan ketepatan waktu dalam pengiriman)

Nilai LPI diperoleh dari pembobotan rata-rata keenam komponen pembentuknya yang telah dijelaskan sebelumnya pada 2.3.2. Nilai LPI berada pada kisaran antara $1 \mathrm{~s} / \mathrm{d} 5$, dimana semakin tinggi nilai LPI berarti dapat dikatakan bahwa semakin baik performansi logistic dari negara yang bersangkutan.

\subsection{Purchasing Manager's Index (PMI)}

PMI merupakan indikator yang diperoleh dari survei bulanan terhadap perusahaanperusahaan swasta dalam suatu negara untuk memperoleh gambaran tentang kondisi kinerja sektor industri. PMI diperkenalkan pertama kalinya pada tahun 1982 oleh US. Department of Commerce (DOC) dan Institute of Supply Management (ISM). Saat ini dua penyedia data (provider) PMI utama adalah the Institute for Supply Management (ISM) yang berbasis di Amerika Serikat dan Markit Group. Ada beberapa sektor yang tercakup dalam indikator PMI, yaitu sektor jasa (Services-PMI), sektor kontruksi (Construction-PMI), dan sektor manufaktur (M-PMI).

US Department of Commerce mengklasifikasikan 5 (lima) komponen pembentuk PMI, yaitu new order (pemesanan baru), produksi, employment, supplier deliveries, serta inventori. Tiap komponen tersebut memiliki bobot yang berbeda (Tabel 1) yaitu:

Tabel 1 Bobot Komponen Penyusun M-PMI

\begin{tabular}{|l|c|}
\hline \multicolumn{1}{|c|}{ Komponen } & Bobot \\
\hline $\begin{array}{l}\text { New Orders (Pemesanan } \\
\text { Baru }\end{array}$ & 0.30 \\
\hline Output (Hasil) & 0.25 \\
\hline
\end{tabular}




\begin{tabular}{|l|c|}
\hline Employment & 0.20 \\
\hline $\begin{array}{l}\text { Supplier's Delivery Times } \\
\text { (Waktu Pengiriman } \\
\text { Supplier) }\end{array}$ & 0.15 \\
\hline Inventory (persediaan) & 0.10 \\
\hline
\end{tabular}

Nilai M-PMI 50 berarti bahwa variabel tidak mengalami perubahan. Sementara nilai $\mathrm{M}$ PMI> 50 mengindikasikan bahwa sektor industri mengalami peningkatan, sebaliknya nilai $\mathrm{P}<50$ mengindikasikan sektor industri mengalami penurunan.

\subsection{Penelitian Terdahulu}

Beberapa penelitian yang menjadi referensi pada penelitian ini disajikan sebagai berikut. Penelitian yang berkaitan dengan LPI diantaranya dilakukan oleh Ojala dan Celebi (2015) yang menganalisis kinerja logistik negara dalam kaitannya dengan komponen kebijakan yang mempengaruhi peraturan, prosedur, dan operasi logistik dan perdagangan dengan studi kasus negara Turki. Metode yang digunakan adalah metode kualitatif melalui analisa yang komprehensif tentang elemen-elemen LPI dalam mengidentifikasi penyebab bottleneck yang berdampak pada persaingan internasional. Hasil dari penelitian ini adalah perlunya mendorong kebijakan dalam rangka meningkatkan kinerja logistik melalui penerapan kebijakan yang efisien negara secara signifikan dapat meningkatkan kemampuan mereka dalam perdagangan internasional yang kompetitif.

Penelitian lainnya dilakukan oleh Bizoi and Sipos (2014) yang meneliti tentang performansi logistik dan pengembangan ekonomi melalui studi komparasi terhadap negara-negara yang tergabung dalam Uni Eropa. Indikator yang digunakan pada penelitian tersebut adalah LPI dan GDP. Dari penelitian tersebut diperoleh hasil bahwa terdapat kaitan yang sangat erat antara LPI dengan pengembangan ekonomi yang direpresentasikan melalui GDP. Hubungan antara LPI dengan indikator ekonomi linnya juga pernah diteliti oleh Erkan (2014 : 12371254). Hasil dari penelitian tersebut adalah bahwa terdapat hubungan yang erat antara GCI (Global Competitiveness Index) yang salah satu komponennya adalah infrastruktur dengan LPI.

Sementara itu penelitian yang berkaitan dengan m-PMI antara lain dilakukan oleh Kang dan Yang (2013: 6174-6177). Mereka menganalisis korelasi antara FDI inflows dengan M-PMI untuk mengukur pembangunan nasional sektor industri di Cina. Hasilnya ditemukan bahwa FDI memiliki pengaruh positif terhadap m-PMI, namun tidak berlaku sebaliknya. Khundrakpam dan George (2012) melakukan analisa empiris tentang hubungan antara WPI dengan m-PMI di India. Dari penelitian ini ditemukan bahwa M-PMI dapat dijadikan sebagai indikator yang bagus dalam memprediksi perubahan pada WPI. Aprigliano (2011) menganalisis kaitan antara PMI dengan Industrial Production Index (IPI) dengan mempertimbangkan pengaruh krisis ekonomi yang baru terjadi. Penelitian ini diharapkan akan memberikan alternatif bagi pembuat kebijakan para praktisi atau manajer perusahaan untuk memanfaatkan data M-PMI untuk mengukur kinerja sektoral.

\section{METODE PENELITIAN}

Metode yang digunakan adalah studi komparatif secara kualitatif dilakukan melalui pemetaan kondisi kinerja industri manufaktur Indonesia dibandingkan dengan negara ASEAN lainnya didasarkan pada nilai LPI dan M-PMI yang dimiliki oleh tiap negara ASEAN.

Pada penelitian ini terdapat dua indikator yang akan dianalisis, yaitu M-PMI dan LPI. Tabel 2 menunjukkan bahwa data yang digunakan adalah data sekunder yang terdiri dari data LPI diperoleh dari data World Bank (Bank Dunia). Sementara data M-PMI dari hasil survei yang dilakukan oleh Markit Grup. 
Tabel 2. Sumber Data

\begin{tabular}{|c|l|l|}
\hline No & \multicolumn{1}{|c|}{ Jenis Data } & Sumber Data \\
\hline $\mathbf{1}$ & $\begin{array}{l}\text { Data LPI negara } \\
\text { Asean }\end{array}$ & World Bank \\
\hline $\mathbf{2}$ & $\begin{array}{l}\text { Data sekunder M- } \\
\text { PMI negara Asean } \\
\text { versi Markit }\end{array}$ & Markit Group \\
\hline
\end{tabular}

\section{HASIL DAN PEMBAHASAN}

\subsection{Gambaran umum LPI Indonesia}

Data terakhir LPI bank dunia menempatkan Indonesia pada posisi ke-53 dari 160 negara dengan skor 3.08. Meskipun nilainya naik namun hanya mampu membuat Indonesia bergerak enam peringkat dibanding tahun sebelumnya.

Nilai skor total LPI diperoleh dari 6 (elemen) penyusunnya, yakni kepabeanan, infrastruktur, kemudahan pengiriman, layanan logistik, tracking and tracing, serta ketepatan waktu pengiriman. Dalam kurun waktu 2007 hingga 2014 skor LPI yang mengalami peningkatan terbesar adalah antara tahun 2010 hingga 2012. Elemen penggerak terbesar peningkatan tersebut berasal dari peningkatan layanan logistik.

Distribusi dari nilai LPI dapat dikategorikan kedalam 4 tingkatan kuantil yaitu logistics unfriendly, Partial performers, consistent performers, dan logistics friendly. Logistics unfriendly merupakan klasifikasi untuk negara dengan kinerja logistik yang tidak bersahabat (parah). Partial performers merupakan klasifikasi negara-negara dengan hambatan logistik yang masih tinggi umumnya dengan tingkat pendapatan lowmiddle. Sementara consistent performers merupakan klasifikasi untuk negara dengan tingkat pendapatan low middle namun kinerja logistiknya lebuh tinggi dibanding negara lain dengan tingkat pendapatan yang sama. Sementara logistics friendly merupakan klasifikasi untuk negara yang kondisi logisitiknya sangat bersahabat (baik). Indonesia pada tahun 2014 mendapatkan nilai LPI 3.08 dimana nilia ini masuk ke kuantil ketiga yaitu consistent performers. Meningkat dari beberapa tahun sebelumnya yang masih dalam zona partial performers.

Jika ditinjau dari enam komponen penyusun LPI, dalam dua tahun terakhir (2012-2014) komponen kemudahan pengiriman, tracking and tracing, dan elemen ketepatan waktu pengiriman mengalami penurunan skor nilai. Sementara itu untuk komponen kepabeanan, infrastruktur, dan layanan logistik Indonesia mengalami peningkatan. Kenyataan ini menunjukkan masih banyak faktor yang perlu untuk dibenahi terkait dengan peningkatan kinerja logistik di Indonesia.

\subsection{Perbandingan LPI Indonesia dengan negara ASEAN}

Analisa perbandingan dilakukan hanya dengan beberapa negara ASEAN yakni Singapura, Malaysia, Thailand, Vietnam, dan Filipina. Tiga negara lainnya yakni Laos, Kamboja, dan Myanmar tidak diikutkan dalam perbandingan ini karena posisi ketiga negara itu jauh berada di bawah Indonesia (peringkat 100 ke atas). Sementara Brunei Darussalam memang tidak diikutsertakan dalam perhitungan LPI dari World Bank. Berikut posisi kinerja logistik Indonesia dibandingkan dengan beberapa negara ASEAN.

secara keseluruhan kinerja logistik Indonesia masih berada di bawah negara Singapura, Malaysia, dan Thailand. Sementara jika dibandingkan Vietnam Indonesia unggul di sisi layanan logistik dan ketepatan waktu pengiriman. Elemen yang memiliki skor teendah dibanding lima negara ASEAN lainnya adalah kepabeanan dan kemudahan pengiriman.

Dari Gambar 1 dapat dilihat bahwa nilai LPI overall tahun 2014 masih di bawah Malaysia, Vietnam, dan Thailand. Singapura yang 
masuk di dalam top performer dalam LPI 2014 ini masih terlalu superior dibanding negara tetangganya di ASEAN. Oleh karena itu, ada baiknya Indonesia melihat pada ketiga negara (Malaysia, Thailand, dan Vietnam) dalam melakukan benchmarking peningkatan LPI.

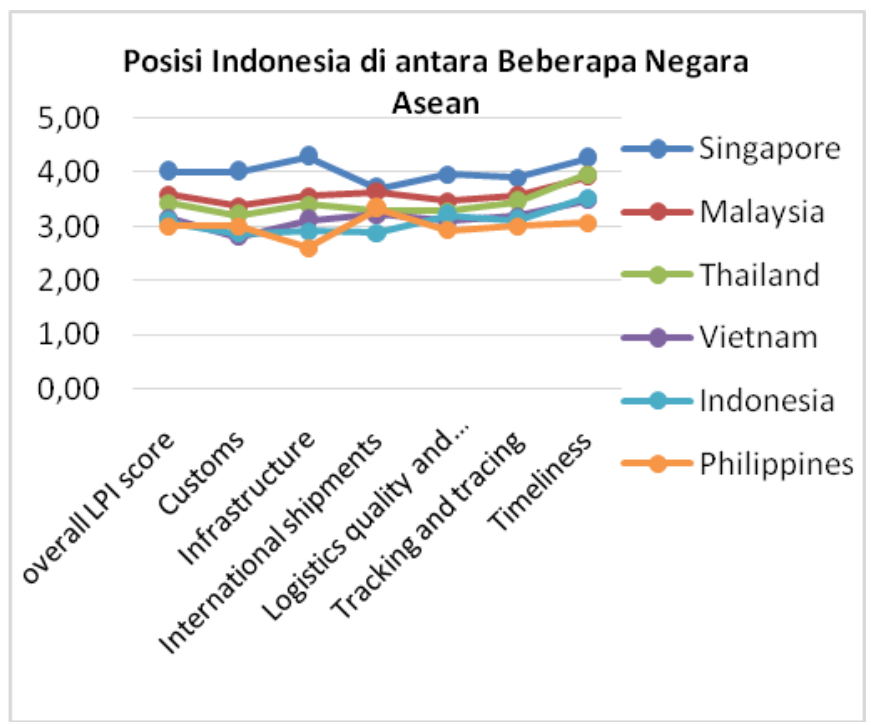

Gambar 1 | Perbandingan LPI Indonesia dengan negara ASEAN lainnya

\subsection{Analisa Perbaikan Elemen LPI Indonesia}

\subsubsection{Elemen Kepabeanan}

Ada beberapa hal yang bisa ditingkatkan untuk memperbaiki sektor kepabeanan Indonesia, antara lain, peningkatan efisiensi pengurusan kepabeanan dan perijinan, perbaikan waktu penyelesaian perijinan (kecepatan dan variasi antar kantor regional), komputerisasi dan Integrasi manajemen otoritas bea cukai dan perijinan perbatasan (border management), serta peningkatan fasilitas ekspor-impor (Improvement of border facilities).

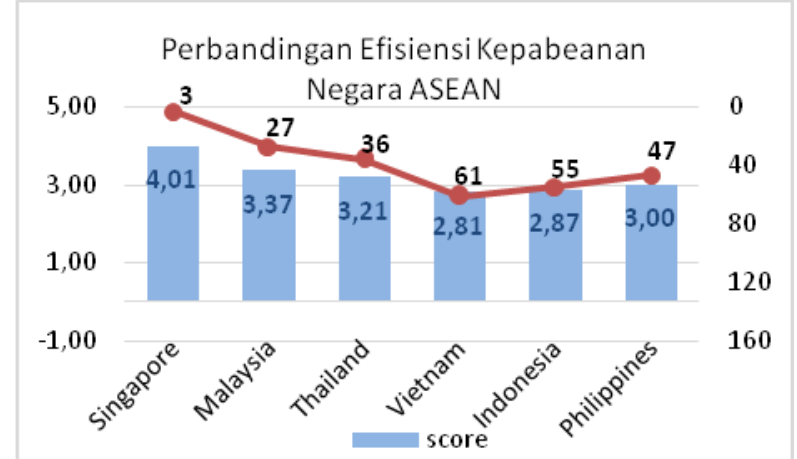

Gambar 2 |Perbandingan tingkat efisiensi kepabeanan Indonesia dengan negara ASEAN

Dari Gambar 2 terlihat bahwa tingkat efisiensi penyelesaian perijinan kepabeaan Indonesia (nilai $=2.87$ ) hanya lebih baik dari Vietnam (2.81), Kamboja (2.67), dan Myanmar (1,97). Singapura yang masuk top performer dalam LPI 2014 ini masih terlalu superior dibanding negara tetangganya di ASEAN. Oleh karena itu, ada baiknya Indonesia melihat pada ketiga negara (Malaysia, Thailand, dan Filipina) dalam melakukan benchmarking peningkatan LPI. Pekerjaan rumah yang besar dalam kaitannya dengan urusan kepabeanan Indonesia , diantaranya:

Tabel 2 Analisa Kepabeanan Indonesia

\begin{tabular}{|c|c|c|}
\hline Komponen & Nilai & Analisa \\
\hline $\begin{array}{l}\text { Transparansi } \\
\text { bea cukai }\end{array}$ & $23.08 \%$ & $\begin{array}{l}\text { Indonesia menempati } \\
\text { nilai terendah untuk } \\
\text { tingkat keterbukaan } \\
\text { dalam urusan } \\
\text { kepabeanan. Indonesia } \\
\text { bisa belajar dari } \\
\text { Singapura }(100 \%) \text {, } \\
\text { Filipina }(66,67 \%) \text {, dan } \\
\text { Thailand (50\%) dalam } \\
\text { peningkatan tranparansi } \\
\text { kepabeanan. }\end{array}$ \\
\hline $\begin{array}{l}\text { Transparansi } \\
\text { lembaga } \\
\text { perbatasan } \\
\text { lainya }\end{array}$ & $38.46 \%$ & $\begin{array}{l}\text { Indonesia hanya lebih } \\
\text { baik dari Vietnam untuk } \\
\text { transparansi lembaga } \\
\text { perbatasan lainya. } \\
\text { Singapura }(100 \%) \text {, } \\
\text { Malaysia }(66.67 \%) \text {, } \\
\text { Thailand }(50 \%) \text {, dan } \\
\text { Filipina (50\%) }\end{array}$ \\
\hline
\end{tabular}




\begin{tabular}{|c|c|c|}
\hline $\begin{array}{l}\text { Penyediaan } \\
\text { informasi } \\
\text { yang } \\
\text { memadai } \\
\text { dan tepat } \\
\text { waktu } \\
\text { mengenai } \\
\text { adanya } \\
\text { perubahan } \\
\text { peraturan }\end{array}$ & $30.77 \%$ & $\begin{array}{l}\text { Untuk Penyediaan } \\
\text { informasi yang } \\
\text { memadai dan tepat } \\
\text { waktu mengenai adanya } \\
\text { perubahan peraturan, } \\
\text { Indonesia lebih baik } \\
\text { dari Vietnam }(28,57 \%) \text {, } \\
\text { tertinggal jauh dari } \\
\text { Singapura }(85,70 \%) \text { dan } \\
\text { Thailand }(50 \%)\end{array}$ \\
\hline $\begin{array}{l}\text { Proses bea } \\
\text { cukai yang } \\
\text { dipercepat } \\
\text { bagi para } \\
\text { pedagang } \\
\text { dengan } \\
\text { tingkat } \\
\text { kepatuhan } \\
\text { yang tinggi. }\end{array}$ & $30.77 \%$ & $\begin{array}{l}\text { Untuk proses bea cukai } \\
\text { yang dipercepat bagi } \\
\text { para pedagang dengan } \\
\text { tingkat kepatuhan yang } \\
\text { tinggi, Indonesia hanya } \\
\text { lebih baik dari Vietnam } \\
(14,29 \%) \text {, tertinggal } \\
\text { jauh dari Singapura } \\
(85,71 \%) \text {, Malaysia } \\
(66.67 \%) \text {, Filipina } \\
(66,67 \%) \text {, dan Thailand } \\
(50 \%) \text {. }\end{array}$ \\
\hline
\end{tabular}

Dalam A World Bank Group Flagship Report diketahui bahwa saat ini masih terdapat disparitas pelayanan antar wilayah regional di Indonesia, sebagai contoh Jakarta dan Surabaya dimana waktu border compliance (pengurusan ijin impor) di Surabaya jauh lebih lama (dua kali lipat) dibanding Jakarta, meskipun dari sisi harga Surabaya lebih murah dengan selisih USD 8 . Untuk meningkatkan kinerja logistik Indonesia maka langkah awal yaitu pertama, mengurangi kesenjangan pelayanan baik waktu dan biaya antara kantor wilayah regional dan kedua, meningkatkan waktu respon dan waktu penyelesaian pekerjaan kepabeanan secara keseluruhan dengan memanfaatkan integrasi layanan INSW (Indonesian National Single Windows).

Beberapa kebijakan pemerintah telah dilakukan untuk mempermudah proses kepabeanan Indonesia, antara lain INSW, risk based inspection, serta EDI (Electronic Data Interchange). Indonesia telah memiliki pertukaran data elektronik (EDI) yang merupakan sistem dalam operasi untuk pengajuan dokumentasi pabean sejak tahun 1997. Hal ini dihubungkan ke INSW, yang dilaunching pada tahun 2007. Pengawasan dan pelayanan perizinan melalui sistem INSW merupakan loket elektronik tunggal untuk penyelesaian perizinan impor ekspor serta pengurusan dokumen kepabeanan dan kepelabuhanan. Hasilnya di tahun 2011 melalui INSW waktu ekspor dapat dikurangi. Namun di tahun 2015 perdagangan internasional kembali mengalami hambatan akibat sarana bongkar muat yang tidak mencukupi pada dua pelabuhan besar Indonesia yakni Tanjung Priok dan Tanjung Perak (Surabaya).

Jika dilihat dari sarana dan prasarana perdagangan internasional (ekpor impor), maka kondisi Indonesia tertinggal dalam beberapa hal: (i) pemenuhan kriteria mutu pengiriman, (ii) waktu penyelesaian perijinan bongkar muat, bea cukai, dan inspeksi/pengujian teknis, dan (iii) perbaikan waktu tunggu ekspor melalui bandara atau pelabuhan. Dalam hal pemenuhan kriteria mutu pengiriman, Indonesia berada dalam posisi paling rendah dengan $70.19 \%$. Peningkatan dapat dilakukan dengan perbaikan fasilitas bongkar muat, fasilitas pergudangan di pelabuhan, dan juga kualitas layanan logistik nasional baik truk, kapal laut, maupun kereta api. Sementara terkait waktu penyelesaian perijinan bongkar muat, bea cukai, dan inspeksi/pengujian teknis, penyelesaian ijin dan kepabeanan tanpa inspeksi di Indonesia membutuhkan waktu 2 hari sedangkan di Singapura tidak sampai 1 hari. Malaysia, Vietnam, dan Thailand masing-masing mampu menyelesaikan dalam 1 hari. Untuk memperbaiki masalah fasilitasi perdagangan internasional ini maka Indonesia harus mampu memangkas waktu dan mengejar ketertinggalan dari negara tetangga. Program INSW memang sudah diinisiasi salah satunya untuk mengatasi hal ini, namun peningkatan sarana dan prassaran fisik on site dipelabuhan harus ditingkatkan karena masalah waktu penyelesaian yang panjang bersumber dari sana. Adapun untuk 
kepabeanan dengan inspeksi maka Indonesia mempunyai durasi penyelesaian yang semakin panjang dan jauh lebih lama dibandingkan dengan negara ASEAN lain. Penyelesaian perijinan tipe ini membutuhkan waktu 5 hari sama dengan Filipina padahal negara lain hanay memerlukan waktu 1-2 hari saja. Untuk mengatasi hal ini maka sebaiknya pemerintah meningkatkan fasilitas inspeksi dan pengujian teknis komoditas ekspor-impor baik dari sisi SDM maupun peralatan uji. Dalam hal waktu tunggu ekspor melalui bandara atau pelabuhan, negara ASEAN lain mampu menyelesaikan pengiriman barang ekspor dengan 1-2 hari sedangkan Indonesia membutuhkan waktu hingga 3 hari. Fasilitas pelayanan kargo di Bandara dan fasilitas bongkar muat di pelabuhan harus segera ditingkatkan untuk memangkas lead time ini.

\subsubsection{Elemen Infrastruktur Transportasi}

Dalam sub bab berikut akan dibahas hal-hal berkaitan dengan komponen sarana dan prasarana perhubungan di Indonesia termasuk kualitas perhubungan di Indonesia dan perbandingannya dengan negara inti didalam ASEAN. Nilai LPI untuk komponen sarana perhubungan dapat dilihat pada Gambar 3, dimana nilai LPI untuk komponen tersebut Indonesia pada peringkat 56 dengan nilai 2,92 dan tertinggal dari Singapura $(4,28)$, Malaysia $(3,56)$, Thailand $(3,40)$, dan Vietnam $(3,11)$.

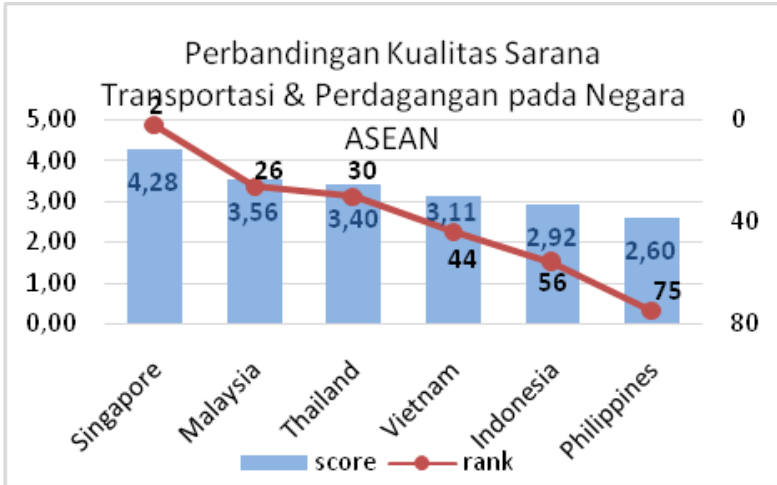

Gambar 3 | Perbandingan Kualitas Sarana Transportasi Negara ASEAN dalam LPI 2014
Langkah perbaikan yang dapat dilakukan antara lain: (i) Peningkatan kualitas sarana prasarana transportasi dan perdagangan, (ii) pembangunan penghubung baru, serta (iii) peningkatan partisipasi swasta dalam penyediaan infrastruktur perhubungan. Perbaikan kualitas sarana dan prasarana transportasi dapat dilakukan melalui peningkatan dan perbaikan sarana yang terdapat pada bandara, pelabuhan, jalan raya, kereta api, pergudangan dan fasilitas transloading, serta fasilitas ICT. Dalam hal pembangunan penghubung baru, Indonesia masih memerlukan banyak peningkatan. Dalam Global Competitiveness Report 20132014 dinyatakan bahwa untuk kualitas infrastruktur udara, jalan raya, serta pelabuhan posisi Indonesia masih berada di bawah Singapura, Malaysia, dan Thailand. Sementara untuk infrastruktur jereta api Indonesia menempati posisi ke-3 Asean setelah Singapura dan Malaysia. Peningkatan penghubung baru salah satunya dapat dilakukan melalui peningkatan investasi pada infrastruktur transportasi. Dalam kurun waktu 2005 hingga 2014 investasi untuk pembiayaan infrastruktur transportasi di Indonesia mengalami fluktuasi dari tahun ke tahun yang besarnya berkisar antar 3\% sampai dengan 5\%. Nilai ini sebaiknya dapat lebih ditingkatkan di masa yang akan datang. Begitu juga dengan keterlibatan swasta dalam penyediaan infrastruktur perhubungan. Peningkatan proyek Investasi kerjasama pemerintah dan swasta harus senantiasa terus dilakukan seperti dalam pembangunan jalan tol, bandara internasional, pembangunan sistem antar moda yang terintegrasi antara bandara, dan kereta api serta antara pelabuhan dengan kereta api.

\subsubsection{Elemen Kemudahan Pengiriman Barang}

Dalam sub bab ini akan dibahas kondisi kemudahan pengiriman barang dalam nilai LPI tahun 2014. Pertama, akan dibahas perbandingan kemudahan pengiriman barang di Indonesia dengan beberapa negara ASEAN. Kedua, akan dianalisa kemungkinan 
peningkatan berkaitan dengan pengiriman barang di Indonesia dalam semangat meningkatkan kinerja logistik Indonesia atau peningkatan nilai LPI untuk beberapa tahun kedepan.

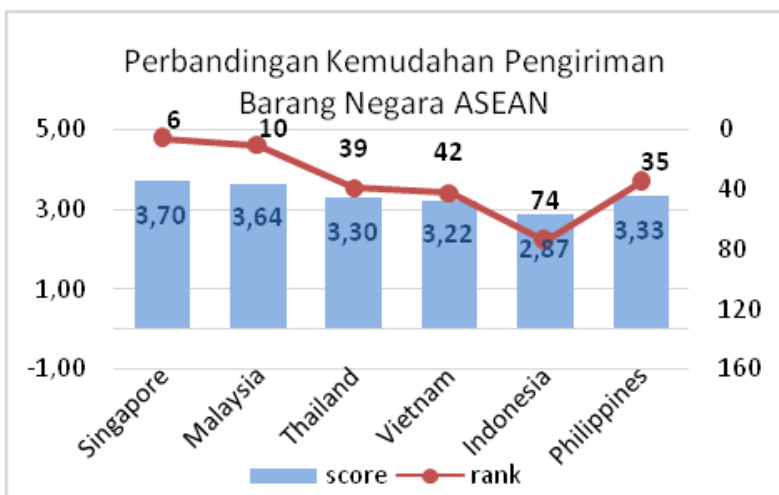

Gambar 4 | Kemudahan Pengiriman Barang Negara ASEAN dalam LPI 2014

Dari Gambar 4 terlihat bahwa Indonesia menempati urutan terbawah dalam penilaian LPI untuk komponen kemudahan dalam pengiriman barang. Indonesia mendapatkan nilai 2.87 dan diperingkat ke 74 , tertinggal dari Vietnam di posisi 42 dengan nilai 3.22 dan Thailand di peringkat 39 dengan nilai 3.30.

Perbaikan yang dapat dilakukan antara lain evaluasi biaya pengiriman terutama biaya ekspor serta promosi moda transportasi murah.Sebagai negara maritim, dalah hal biaya transportasi laut, udara, maupun laut, Indonesia sebaiknya belajar dari negara Malaysia dan Vietnam yang dapat menekan biaya logistik pada kisaran US\$200-300.

\subsubsection{Elemen Kualitas Pelayanan Logistik}

Berikut posisi Indonesia dibandingkan negara ASEAN lainnya dilihat dari kompetensi dan kualitas jasa layanan logistik (Gambar 4).

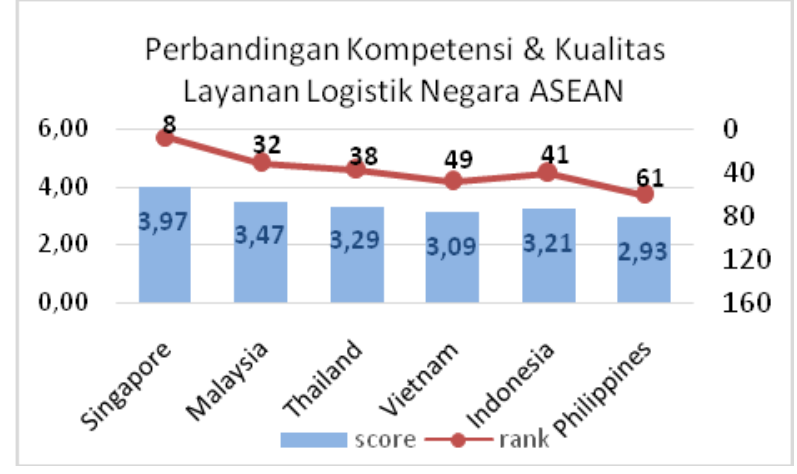

Gambar 5 | Kompetensi dan Kualitas Layanan Logistik ASEAN menurut LPI 2014

Dari Gambar 5 dapat dilihat bahwa Indonesia lebih baik dari Vietnam dan Filipina dalam penilaian kompetensi dan kualitas layanan logistik dengan nilai 3.21 atau peringkat 41 secara global dengan nilai 3.21. Dari skala 5, Singapura mendapat nilai tertinggi dengan 3,97 diperingkat 8 dunia. Dengan selisih yang tidak begitu jauh dengan Malaysia ( peringkat: 38/nilai: 3,47) dan Thailand (38/3,29), Indonesia dapat menargetkan peningkatan untuk menggeser posisi kedua negara tersebut. Peningkatan kompetensi dan kualitas layanan logistik nasional dapat dilakukan diantaranya melalui penyediaan Sumber Daya Manusia (SDM) bidang logistik baik melalui pendidikan formal maupun non formal, sertifikasi personel logistik, serta peningkatan penunjang industri nasional dengan keterlibatan pihak swasta.

\subsubsection{Elemen Penelusuran Pengiriman}

Dalam hal kemampuan lacak dan kemampuan telusur pengiriman barang, Indonesia berada pada peringkat 5 ASEAN di bawah Singapura, Malaysia, Thailand, dan Vietnam (Gambar 6). Untuk perbaikan keterusuran dan keterlacakan pengiriman barang, Indonesia harus belajar dari Singapura yang berada pada posisi teratas ASEAN dengan nilai LPI 3,9. 


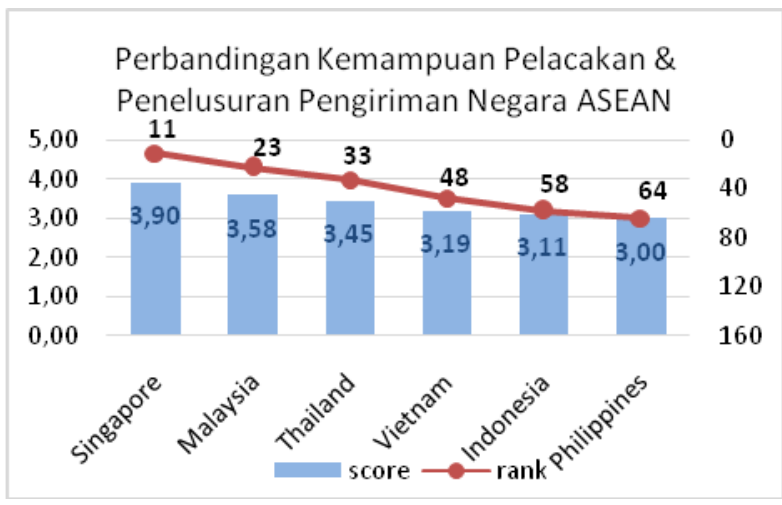

Gambar 6 | Gambaran ketertelusuran dan keterlacakan pengiriman barang dalam LPI 2014

Rencana tindakan perbaikan untuk sistem ketertelusuramn pengiriman ini diantaranya dengan pemanfaatan teknologi informasi dalam sistem logistik nasional. Pengintegrasian berbagai proses dan entitas bisnis dalam aktivitas logistik pada dasarnya merupakan sharing informasi yang dimiliki dan dihasilkan oleh berbagai pihak yang terlibat dalam rantai logistik. Hal ini menjadikan teknologi informasi menjadi alat bantu penting dalam memonitor pengelolaan seluruh simpul kegiatan yang terkait dengan logistik. Sebagai contoh penerapan teknologi sistem informasi pada pengiriman barang menggunakan truk dan trailer. Penerapan IT dalam hal ini berperan dalam menyiapkan database pengusaha truk, armada dan pengemudi di Indonesia, termasuk informasi ruang dan muatan, yang memungkinkan masyarakat dapat mengakses interkoneksi data antara operator dan pengguna truk.

\subsubsection{Elemen Ketepatan Pengiriman}

Dalam hal ketepatan waktu pengiriman Indonesia lebih baik daripada Vietnam dan Filipina tetapi masih tertinggal dari Malaysia, Thailand, dan Singapura (Gambar 7).

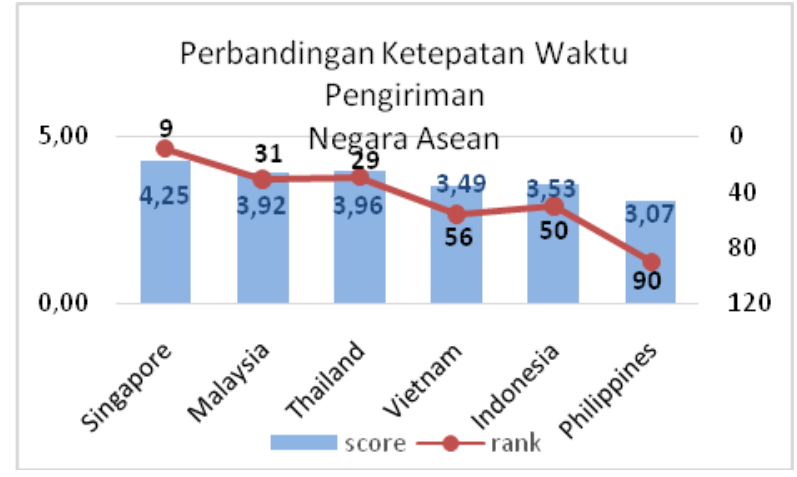

Gambar 7| Kondisi ketepatan waktu pengiriman dalam LPI 2014

Dari survei LPI tentang penyebab keterlambatan pengiriman diketahui bahwa Indonesia masih mempunyai masalah atau penghambat berupa inspeksi pra pengiriman, maritime transhipment, dan adanya permintaan biaya tidak resmi. Indonesia harus banyak belajar dari Singapura dan Thailand yang berhasil mengeliminasi penghambat ketepatan waktu pengiriman dengan sangat baik, antara lain perbaikan prosedur inspeksi pra pengiriman, prosedur pengiriman transit antar moda pada transportasi laut, serta penertiban sistem pembayaran pada pengiriman barang sehingga tidak dimungkinkan lagi pemungutan biaya secara ilegal.

\subsection{Gambaran Umum Manufacturing Purchasing Manager Index (M-PMI) Indonesia}

Pada awal tahun 2015 kondisi manufaktur Indonesia mengalami kondisi kurang lebih samadengan akhir tahun 2014. Nilai rata-rata M-PMI Indonesia tahun 2014 adalah 50,5 yakni lebih rendah 0,98 poin dibanding tahun 2013. Untuk tahun 2015 (Januari - Sept 2015) nilai rata-rata ini makin menurun menjadi hanya 47,5. Artinya sepanjang tahun 2015 kondisi industri manufaktur di Indonesia mengalami kontraksi (penurunan). Dari analisis survey para ahli diketahui bahwa penyebab utama rendahnya nilai M-PMI Indonesia sepanjang tahun 2014 hingga 2015 disebabkan karena rendahnya permintaan 
baru yang mengakibatkan faktor-faktor lain juga menurun. Nilai terendah sepanjang sejarah survei terjadi pada bulan maret 2015 . Kondisi ini terus berlanjut dan tidak banyak mengalami perbaikan hingga Setember 2015.

\subsection{Perbandingan m-PMI Indonesia dengan negara lain}

Gambar 8 menunjukkan bahwa dalam kurun waktu Desember 2011 hingga September 2015 nilai m-PMI Indonesia paling rendah jika dibandingkan dengan Singapura dan Vietnam.

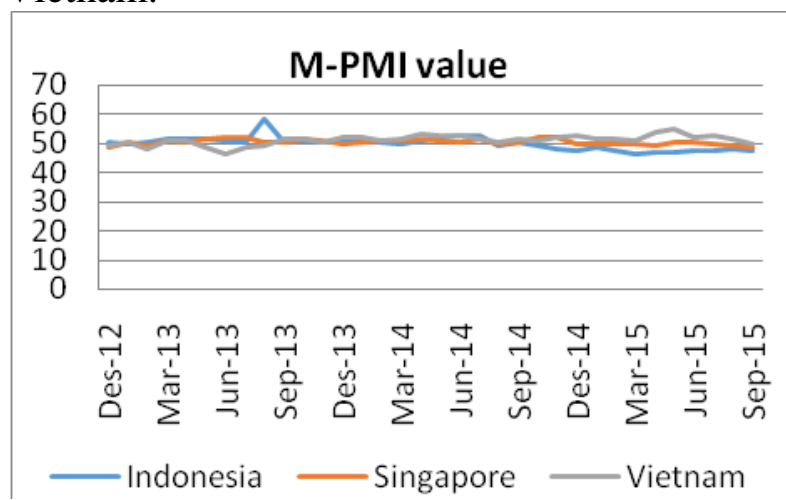

Gambar 8 | Perbandingan m-PMI Indonesia dengan Singapura dan Vietnam

\subsection{Analisa perbaikan M-PMI Indonesia}

M-PMI melibatkan faktor ekonomi dan produksi dengan logistik sebagai salah satu elemennya yang saling terkait. Salah satu cara untuk meningkatkan jumlah permintaan adalah melalui penurunan suku bunga bank. Diharapkan melalui penurunan suku bunga bank dapat menarik permintaan baru, dan dapat meningkatkan jumlah produksi. Selain itu perbaikan pada produktivitas industri manufaktur, seperti perbaikan metode kerja dan kepastian pengiriman barang dari supplier

\subsection{Perbandingan dan Hubungan antara LPI dan M-PMI}

Analisa empiris dilakukan dengan menganalisa perubahan atau variasi nilai $\mathrm{M}$ PMI untuk nilai LPI yang berbeda. Untuk mengetahui sejauh mana nilai LPI berpengaruh terhadap nilai m-PMI Indonesia. Dikarenakan set data yang tersedia terbatas maka nilai LPI yang akan digunakan dalam analisa hubungan ini terbatas untuk tahun 2012 dan 2014 saja. Berikut perbandingan antara indeks m-PMI Indonesia pada saat LPI=2.94 dan LPI = 3.08 (Gambar 9).

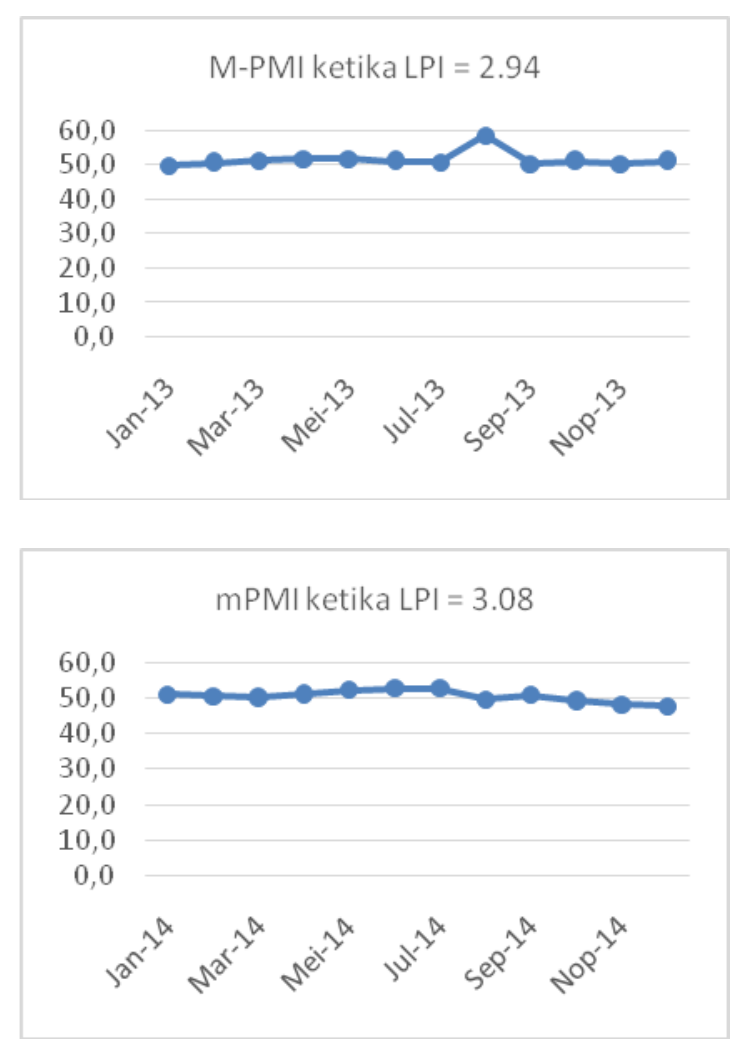

Gambar 9 | Analisa Perubahan atau Variasi nilai M-PMI untuk Nilai LPI yang Berbeda

Pada saat LPI Indonesia 2.94 (tahun 2012), fluktuasi indeks m-PMI Indonesia berada pada kisaran 49.7 hingga 58.5 dengan variansi sebesar 2,29. Pada tahun 2014, saat LPI Indonesia mengalami kenaikan menjadi 3.08, indeks m-PMI Indonesia mengalami fluktuasi pada kisaran 47.6 dan 52.7 dengan variansi sebesar 1,69. Dari data tersebut terlihat bahwa semakin tinggi indeks LPI, maka rentangan tingkat fluktuasi m-PMI makin kecil.

\section{KESIMPULAN DAN SARAN}

\subsection{Kesimpulan}


Selama tahun 2014 Komponen LPI Indonesia yang masih tertinggal dibandingkan dengan 5 negara ASEAN utama (Singapura, Malaysia, Thailand, Vietnam, dan Filipina) adalah komponen kepabeanan dan pengiriman. Sementara dalam kurun waktu 2007 hingga 2014 komponen yang mendapat nilai terendah adalah kepabeanan. Hal ini menunjukkan bahwa komponen kepabeanan merupakan komponen kritis yang harus segera diperbaiki.

Dilihat dari M-PMI, elemen dari M-PMI saling terkait sehingga diperlukan kebijakankebijakan khusus dalam peningkatan M-PMI baik faktor ekonomi maupun peningkatan produktivitas produksi dimana logistik menjadi salah satu elemennya. Salah satunya adalah melalui penurunan tingkat suku bunga. Melalui peningkatan suku bunga diharapkan dapat meningkatkan jumlah permintaan dan hal ini juga dapat memacu jumlah output (produksi). Selain itu peningkatan M-PMI juga dapat dilakukan melalui perbaikan produktivitas produksi seperti perbaikan terhadap metode kerja dan kepastian pengiriman supplier.

M-PMI lebih dipengaruhi oleh faktor ekonomi (seperti FDI, IPI) dibanding dengan LPI. Namun secara umum dapat disimpulkan bahwa ketika nilai LPI meningkat maka nilai M-PMI akan cenderung lebih stabil.

\subsection{Saran}

Dalam rangka meningkatkan kemampuan Indonesia menghadapi persaingan internasional yang kompetitif, pemerintah perlu melakukan pembenahan terutama dalam hal kepabeanan. Perbaikan yang dapat dilakukan antara lain melalui peningkatan efisiensi pengurusan kepabeanan dan perijinan, perbaikan waktu penyelesaian perijinan (kecepatan dan variasi antar kantor regional), komputerisasi dan Integrasi manajemen otoritas bea cukai dan perijinan perbatasan (border management), serta peningkatan fasilitas ekspor-impor (Improvement of border facilities).
Untuk penelitian selanjutnya pengukuran LPI dan MPI dapat dilakukan pada rentang waktu yang lebih panjang (artinya data yang diperoleh lebih banyak) sehingga dapat dilakukan pengukuran hubungan antara kedua indikator tersebut secara kuantitatif.

\section{UCAPAN TERIMA KASIH}

Penulis mengucapkan terima kasih kepada reviewer atas masukan dan kontribusinya bagi perbaikan dan pengembangan penelitian ini. Secara khusus ucapan terima kasih juga disampaikan kepada segenap civitas Politeknik APP Jakarta dan semua pihak yang telah membantu hingga terlaksananya penelitian ini.

\section{DAFTAR PUSTAKA}

Aprigliano , V. (2011). The relationship between the $P M I$ and the Italian indexof industrial production and the impactof the latest economic crisis. Working Paper. (http://www.bancaditalia.it/pubblicazioni/temidiscussione/2011/2011-0820/en_tema_820.pdf)

Apriliawan, D, dkk. (2013). Pemodelan Laju Inflasi Di Provinsi Jawa Tengah Menggunakan Regresi Data Panel. Jurnal gaussian, 2 (4), 301-321. http://download.portalgaruda.org/article.php?ar ticle $=120601 \& v a l=4706$

Bizoi, A.C and Sipos, A (2014). Logistics Performance and Economic Development - A Comparison within the European Union . Proceeding of $M A C-E M M$

BPS (2015). Laju Pertumbuhan Kumulatif Produk Domestik Bruto Menurut Lapangan Usaha, 2001-2014

(http://www.bps.go.id/linkTabelStatis/view/id/ $\underline{1213})$

Caraka, R.E, dan Prahutama, A . Pemodelan Regresi Panel pada Data Pendapatan Asli Daerah (PAD) terhadap Dana Alokasi Umum (DAU), Universitas Diponegoro.

Erkan, B (2014). The Importance and Determinants of Logistics Performance of Selected Countries. Journal of Emerging Issues in Economics, Finance and Banking, 3 (6), 1237-1254

Hsiao, C., (2003). Analysis of Panel Data. University of Southern California

Kang, C and Yang, L (2013). An analysis on the Correlation between FDI inflows and Chinese Manufacturing PMI Index. Information and 
Technology Journal, 12 (21), 6174-6177. doi:10.3923/itj.2013.6174.6177

Khundrakpam , J.K. (2013). An Empirical Analysis of the Relationship between WPI and PMIManufacturing Price Indices in India. RBI Working Paper Series, Department Of Economic And Policy Research, 6 (50929). (http://mpra.ub.uni-muenchen.de/50929)

Ojala, L, and Celebi, D (2015). The World Bank's Logistics Performance Index (LPI) and drivers of logistics performance. Proceeding of $M A C$ EMM, OECD.

(http://www.internationaltransportforum.org/jtr c/RoundTables/2015Logistics/Ojala.pdf) 